\title{
ANALISIS STRATEGI PEMBELAJARAN IPA DALAM BUKU TEMATIK KURIKULUM 2013 KELAS IV SD
}

\author{
Alma Pratiwi Husain \\ almaamha09@gmail.com \\ UIN Sunan Kalijaga Yogyakarta
}

\begin{abstract}
This article aims to find out the relevant strategies for use in science lessons, thematic books K-13 class IV theme 2 in MI / SD. The research method used is the library research approach. Data collection is carried out by examining various journals, books and documents both printed and electronic which are relevant to research studies. The results showed that the relevant learning strategies used were experiential learning strategies with experimental methods and field observations. This strategy provides a real picture because students are in direct contact with objects and nature during the learning process. The benefits of this study provide information related to relevant learning strategies for science lessons, thematic books K-13 class IV theme 2 in $\mathrm{MI} / \mathrm{SD}$.
\end{abstract}

Keywords: Learning Strategies, Main Material Science in MI/SD

\begin{abstract}
Abstrak
Artikel ini bertujuan mengetahui strategi yang relevan untuk digunakan pada pelajaran IPA, buku tematik K-13 kelas IV tema 2 di MI/SD. Metode penelitian yang digunakan yaitu pendekatan kepustakaan. Pengumpulan data dilakukan dengan menelaah berbagai jurnal, buku dan dokumen baik cetak maupun elektronik yang relevan dengan kajian penelitian. Hasil penelitian menunjukkan strategi pembelajaran yang relevan digunakan yaitu strategi pembelajaran melalui pengalaman dengan metode eksperimen dan pengamatan lapangan. strategi ini memberikan gambaran yang nyata karena peserta didik berhubungan langsung dengan benda dan alam saat proses belajar. Manfaat hasil penelitian ini memberikan informasi terkait strategi pembelajaran yang relevan untuk pelajaran IPA, buku tematik K-13 kelas IV tema 2 di MI/SD. Memberikan gambaran dan informasi untuk pendidik/guru diberbagai jenjang pendidikan mulai dari SD, SMP, SMA hingga Perguruan Tinggi dalam merencanakan pembelajaran IPA yang inovatif, kreatif dan menyenangkan melalui pemilihan strategi yang tepat.
\end{abstract}

Kata kunci: Strategi Pembelajaran, Materi Pokok IPA di MI/SD 


\section{A. Pendahuluan}

Pendidikan berperan penting dalam mengolah sumber daya manusia. Tujuan pendidikan tidak lain untuk mengembangkan potensi peserta didik, agar ia mampu mengelolanya dan menjadikan potensinya sebagai keahlian yang berguna untuk masa depan. ${ }^{1}$ Proses pendidikan berkaitan dengan peran seorang guru yang tepat memilih strategi pembelajaran dalam menyampaikan materi ajar. Guru memilih strategi sesuai dengan karakteristik peserta didik, bahan ajar, dan suasana belajar. Strategi pembelajaran diartikan sebagai kemampuan yang dimiliki guru dalam mengajar untuk mencapai tujuan pembelajaran yang efektif dan efisien. ${ }^{2}$ Strategi yaitu cara seorang guru memberikan kepahaman tentang materi ajarnya agar kelak bisa diterapkan dalam kehidupan sehari-hari. ${ }^{3}$

Ilmu Pengetahuan Alam (IPA), salah satu mata pelajaran yang terdapat di Sekolah Dasar atau Madrasah Ibtida’iyah. Materi pokok IPA identik dengan kehidupan manusia dan alam sekitarnya. Materi IPA di sekolah difokuskan pada dua aspek. Yang pertama IPA sebagai produk Ilmu Pengetahuan, dan IPA sebagai proses untuk mengetahui. Kemampuan berpikir kritis dapat diperoleh dari materi pelajaran IPA, terkhusus pada jenjang sekolah dasar. Peserta didik akan terasah kemampuan dalam melihat sebuah kejadian. ${ }^{4}$ Pelajaran IPA merupakan proses aktif, sesuai apa yang dirasakan peserta didik, dan peristiwa nyata yang ada disekitarnya. ${ }^{5}$

Strategi pembelajaran disesuaikan dengan materi pelajaran yang disampaikan. Pelajaran IPA yang materinya berkaitan dengan kehidupan manusia dalam proses penyampaiannya harus mencapai pada target

${ }^{1}$ Azimi, Ani Rusilowati, Sulhadi, Pengembangan Media Pembelajaran IPA Berbasis Literasi Sains untuk Siswa Sekolah Dasar, Pancasakti Science Education Journal PSEJ Volume 2 Nomor 2, Oktober 2017, Hal. 145- 145

${ }^{2}$ Harmuni, Strategi Pembelajaran, (Yogyakarta: Insan Madani, 2012), hal. 2

${ }^{3}$ Hamzah B. Uno, Model Pembelajaran, (Jakarta: Bumi Aksara, 2011), hlm. 2

${ }^{4}$ Dw. Ayu Indri Wijayanti , Kt. Pudjawan , I Gd. Margunayasa, Analisis Kemampuan Berpikir Kritis Siswa Kelas V Dalam Pembelajaran Ipa Di 3 Sd Gugus X Kecamatan Buleleng, e-Journal PGSD Universitas Pendidikan Ganesha Jurusan PGSD Volume: 3 No: 1 Tahun 2015

${ }^{5}$ Eli Fauzi Rahma, Peningkatan Aktivitas Belajar Ipa Melalui Strategi Pembelajaran Inkuiri Terbimbing Pada Kelas Ivb Sdn Panggang, Jurnal Pendidikan Guru Sekolah Dasar Edisi 19 Tahun ke-5 2016 
pemahaman yang dapat diimplementasikan dalam kehidupan peserta didik. Faktanya masih ditemui peserta didik yang masih tidak fokus dan kurang aktif dalam proses pelajaran materi IPA. Penelitian yang dilakukan (Eli Fauzi Rahma, 2016) menyatakan permasalahan terkait aktivitas belajar siswa dalam pembelajaran IPA, terdapat beberapa siswa yang tidak memperhatikan guru menjelaskan materi, tidak aktif dalam belajar, dan keterbatasan media pembelajaran yang tersedia. Selain itu penelitian oleh (Neris, 2015) fakta yang ditemukan siswa kurang diberi kesempatan mencurahkan ide yang dimiliki, pemahaman guru mengenai macam-macam strategi pembelajaran masih minim sehingga pembelajaran terkesan monoton.

Berdasarkan penjelasan diatas, peneliti memilih menganalisis strategi pembelajaran IPA dalam buku Tematik kurikulum 2013 kelas IV tema 2. Peneliti merasa bahwa memilih strategi pembelajaran, penting untuk ditentukan sebelum guru melakukan proses pembelajaran termasuk dalam pelajaran IPA. Jenjang yang diambil peneliti adalah kelas IV dimana, kelas IV adalah kelas dasar peserta didik mendapatkan materi IPA, penting untuk guru menanamkan konsep dasar sains pada peserta didik agar tidak mengalami kekeliruan pemahaman sains dari proses awal mengenal materi IPA di jenjang dasar.

Adapun pembahasannya dibahas lebih mendalam terkait analisis strategi pembelajaran IPA dalam buku Tematik Kurikulum 2013 kelas IV tema 2, yang mencakup pengertian, ruang lingkup, karakteristik, fungsi, dan kegunaan strategi pembelajaran, macam-macam strategi pembelajaran menurut karakteristik materi dan tujuan pembelajaran, karakteristik materi pokok IPA di $\mathrm{MI} / \mathrm{SD}$, relevansi strategi pembelajaran dengan karakteristik materi pokok IPA dalam buku tematik kelas IV tema 2 di MI/SD, dan merumuskan strategi pembelajaran yang relevan dan sesuai dengan materi pokok IPA dalam buku tematik kelas IV tema 2 di MI/SD. 


\section{B. Metode Penelitian}

Penelitian ini yaitu studi kepustakaan. Peneletian kepustakaan yaitu pengumpulan data didapatkan dari buku, jurnal, berita, dan penelitian-penelitian terdahulu. Menurut sugiyono, 2012 penelitian kepustakaan yaitu kajian teoritis yang berkaitan dengan nilai, norma pada situasi yang diteliti. ${ }^{6}$

Peneliti menggunakan teknik dokumentasi. Menurut Arikunto, teknik dokumentasi yaitu mencari dokumen-dokumen terkait pembahasan penelitian, yang ditelaah dari buku, catatan, jurnal, dan artikel terkait. ${ }^{7}$

\section{Hasil dan Pembahasan}

\section{Pengertian dan Ruang Lingkup Strategi Pembelajaran}

a. Pengertian Strategi Pembelajaran

Strategi pembelajaran suatu perencanaan yang didesain guru pada saat mengajar, terdapat rangkaian pembelajaran dalam pencapaian proses belajar yang diinginkan. ${ }^{8}$ Guru mempunyai kewenangan dalam mengelola pembelajaran dengan rencana yang telah disusun sebelumnya, agar tercapai proses pembelajaran yang sesuai tujuan belajar. Strategi dari bahasa yunani strategos, terbagi dua kata "stratos" (militer) dan “ago“(memimpin). Diartikan yang lain stratego yaitu merencanakan (to plan). ${ }^{9}$

Menurut Suyono strategi pembelajaran yaitu proses belajar terkait pengelolaan peserta didik, pengelolaan guru, pengelolaan kegiatan pembelajaran, pengelolaan lingkungan belajar, pengelolaan sumber belajar dan penilaian (asesmen) untuk mencapai tujuan belajar yang baik. $^{10}$

${ }^{6}$ Sugiyono, Metode Penelitian Kuantitatif, Kualitatif dan R\&D, (Alfabeta, 2012)

${ }^{7}$ Arikunto.S,Prosedur Penelitian Suatu Pendekatan Praktik, (Rineka Cipta, 2010)

8 AndiPrastowo,Menyusun Rencana Pelaksanaan Pembelajaran (RPP) TematikTerpadu, (Jakarta:Prenada Media, 2015), hlm. 240 2014), hlm. 140

${ }^{9}$ Abdul Majid, Pembelajaran Tematik Terpadu, (Bandung: Remaja Rosdakarya,

${ }^{10}$ Suyono dan Hardianto, Belajar dan pembelajaran: Teori dan konsep Dasar, (Bandung: Remaja Rosdakarya, 2011), hlm. 20 
Kesimpulan penjelasan diatas, strategi pembelajaran yaitu rangkaian aktivitas guru dan peserta didik mewujudkan proses belajar inovatif, kreatif dan menyenangkan dengan menggunakan metode dan media belajar sesuai materi pokok yang diajarkan dalam proses pembelajaran.

b. Ruang Lingkup Strategi Pembelajaran

Efektifitas pembelajaran dilihat pada kuantitas dan kualitas belajar yang didapatkan peserta didik. efisien disini bagaimana guru menggunakan strategi pembelajaran, sesuai seperti materi, efisien waktu dalam proses pembelajaran, fasilitas yang dipakai dan potensi guru saat memberi materi belajar. ${ }^{11}$

Ruang lingkup strategi pembelajaran terdiri atas:

1) Komponen sistem meliputi pendidik/guru, dosen, siswa, mahasiswa, dan pihak yang ikut dalam kegiatan belajar.

2) Jadwal pelaksanaan yang disusun sebelumnya

3) Materi belajar yang akan dipelajari dan telah diklasifikasikan.

4) Tugas pembelajaran dengan kesiapan sebelumnya.

5) Karakter peserta didik yang telah dikelompokkan.

6) pembelajaran tersusun sebelumnya untuk belajar.

7) Teknik penyajian, cara belajar yang cocok, seperti diskusi, penjelasan, eksperimen dan media belajar yang disesuaikan lebih dulu.

Pelaksanaan strategi pembelajaran oleh guru meliputi dimensi makro (umum), dan dimensi mikro (khusus). Dimensi bersifat makro (umum) berkaitan perihal pengembangan dan pembinaan, proses belajar dalam strategi pembelajaran yang dilakukan guru meliputi;

1) Memilih dan menjalankan maksud kegiatan belajar.

2) Menetapkan alur pembelajaran

3) Mengelola bahan ajar yang akan disampaikan

11 Mohammad Asrori, Pengertian, Tujuan dan Ruang Lingkup Strategi Pembelajaran,Jurnal Madrasah, Vol.5. No. 2 Januari- Juni 2013, diunduh pada tanggal 16 Mei 
4) Mengatur waktu pembelajaran

5) Menentukan bentuk aktivitas

6) Memilih metode, tekhnik dalam kegiatan belajar mengajar

7) Pemilihan penggunaan media pembelajaran

8) Menerapkan prinsip-rinsip pembelajaran, mengatur pengembangan iklim pembelajaran, dan melakukan evaluasi

Strategi pembelajaran dimensi bersifat mikro lebih berhubungan pada tindakan operasional dan interaktif guru dikelas. Mencakup pada pelaksanaaan metode, teknik pembelajaran, dan penggunaan media dan sumber pembelajaran. ${ }^{12}$

\section{Karakteristik, fungsi, dan Kegunaan Strategi Pembelajaran}

Karakteristik Strategi Pembelajaran menurut Rangke L Tobing, mengidentifikasi lima karakteristik dalam strategi pembelajaran, yaitu :

1) Tata cara bersifat ilmiah, dalam prosesnya strategi pembelajaran harus sistematik.

2) Akhir belajar terfokus, strategi dalam belajar memberikan hasil yang diperoleh lebih terperinci

3) Lingkungan pembelajaran mendukung, memperhatikan keadaan sekitar untuk proses belajar berlangsung.

4) Mekanisme pelaksanaan, model pembelajaran mampu memberikan kesan terjadi kolaborasi antara peserta didik dengan lingkungan.

Menurut Bruce dan Weil karakteristik strategi pembelajaran, yaitu;

1) Sintaks, memiliki tahapan dalam proses pembelajaran, dimana menggambarkan proses pembelajaran dari strategi dan model pembelajaran tersebut.

2) Sistem sosial, strategi pembelajaran memiliki hubungan antara peran pendidik dan peserta didik. 
3) Prinsip reaksi, seorang guru mampu melihat keadaan dan merespon peserta didik dalam kegiatan belajar.

4) Sistem pendukung, guru melakukan kajian kembali perihal strategi pembelajaran yang akan digunakan, seperti media belajar dan keadaan peserta didik.

5) pembelajaran langsung dan iringan, dampak kegiatan belajar mengarahkan peserta didik pada tujuan, dampak iringan menghasilkan hasil yang lain dalam proses belajar. ${ }^{13}$

Menurut Dick dan Carey, komponen dalam strategi belajar meliputi :

1) Kegiatan pendahuluan, guru memiliki kemampuan membuat kesan menyenangkan diawal pembelajaran.

2) Penyampaian informasi, guru akan merencanakan informasi, konsep kepada peserta didik.

3) Partisipasi, peserta didik diharapkan memberikan partisipasi agar proses pembelajaran berhasil disampaikan.

4) Tes, penilaian dipakai guru dalam mengamati kemampuan dalam menyerap kegiatan belajar yang dilakukan peserta didik.

5) Kegiatan lanjutan, kegiatan lanjutan menindak lanjuti suatu perolehan yang didapatkan peserta didik, jadi ada perbaikan atau evaluasi dari setiap hasil yang diperoleh oleh peserta didik. ${ }^{14}$

Fungsi dan kegunaan strategi belajar dipakai untuk menyajikan informasi yang dibutuhkan saat kegiatan belajar dilakukan. Fungsi dan kegunaan lainnya sebagai metode penyampaian konsep yang telah diidentifikasi sebelumnya melihat dari pedoman pegangan guru berupa buku.

${ }^{13}$ Rangke L Tobing, Setia Adi Hindun, Model-Model Mengajar Metodik Khusus Pendidikan Ilmu Pengetahuan Alam Sekolah Dasar, diunduh pada tanggal 16 Mei 2020 hlm. 5-9

${ }^{14}$ Wahyudin Nur Nasution, strategi Pembelajaran, (Medan, Perdana Publishing, 2017), 


\section{Macam-macam Strategi Pembelajaran Menurut Karakteristik Materi dan Tujuan Pembelajaran}

Guru ketika menyampaikan materi pelajaran tentunya memilih teknik belajar yang telah disesuaikan. Sehingga kegiatan belajar dapat berjalan sesuai harapan. berikut disajikan macam-macam strategi pembelajaran dan metode pembelajaran yang relevan sebagai berikut ${ }^{15}$

Tabel 1. Jenis Strategi dan Metode Pembelajaran

\begin{tabular}{|l|l|}
\hline Strategi & \multicolumn{1}{|c|}{ Metode/cara } \\
\hline Pembelajaran Langsung & - Metode penjelasan/Ceramah \\
& - Metode question/Tanya jawab \\
& - Cara Latihan \\
& - Demonstrasi/praktek konsep \\
\hline Pembelajaran Tidak & - Pembentukan konsep problem \\
Langsung & memperoleh kon \\
& - Solving inkuiri terbimbing \\
\hline Pembelajaran Interaktif & - Latihan sejawat \\
& - Diskusi \\
\hline Pembelajaran Eksperiensial & - Belajar kooperatif berkelompok \\
(pembelejaran Melalui & - Setode Eksperimen \\
Pengalaman) & - Pengamatan Lapangan \\
\hline Pembelajaran Mandiri & - Metode Proyek Penelitian \\
\hline
\end{tabular}

a. Strategi Pembelajaran Langsung (Direct Instruction)

Strategi pembelajaran langsung yaitu guru langsung mentransfer informasi yang dimiliki kepada peserta didik dalam kegiatan pembelajaranya. ${ }^{16}$ Strategi ini meliputi metode ceramah, tanya jawab yang berkaitan tentang aspek sikap, pengetahuan, dan keterampilan, praktek, latihan dan demonstrasi. Strategi ini cocok digunakan untuk mengembangkan sebuah informasi. ${ }^{17}$

\footnotetext{
${ }^{15}$ Andi Prastowo, Menyusun Rencana Pelaksanaan Pembelajaran (RPP) Tematik Terpadu, (Jakarta: Prenada Media, 2015), hlm. 267

${ }^{16}$ Muhamad Afandi, Evi Chamalah, Oktarina Puspita Wardani, Model Dan Metode Pembelajaran Di Sekolah, (Semarang: UNISSULA PRESS, 2013), hlm.16

${ }^{17}$ Abdul Majid, Pembelajaran Tematik Terpadu, (Bandung: Remaja Rosdakarya, 2014), hlm.11
} 
1) Metode ceramah

Metode ceramah, metode secara lisan antara guru kepada peserta didik dalam proses pembelajaran. ${ }^{18}$ Dalam metode ini guru dapat melakukan pembelajaran dengan menyampaikan peristiwa terkini.

2) Metode Tanya jawab

Metode tanya jawab digunakan dengan memberikan beberapa pertanyaan untuk mengulang kembali materi belajar yang sudah dipelajari. Guru memberikan pertanyaan untuk melatih penalar peserta didik.

3) Metode Latihan

Metode latihan dilakukan dengan melatih kemampuan menuntaskan persoalan. Memberikan materi untuk melatih ketangkasan peserta didik. ${ }^{19}$

4) Metode Demonstrasi

Teknik ini dilakukan dengan memperlihatkan suatu proses, atau keadaan, atau benda tertentu yang dipelajari, baik secara nyata maupun tiruan yang sering disertai dengan penjelasan lisan dari seorang guru kepada peserta didiknya. ${ }^{20}$

b. Strategi Pembelajaran Tidak Langsung (Indirect Instruction)

Pembelajaran menggunakan strategi tidak langsung memposisikan guru berperan sebagai fasilitator, sehingga dalam belajar perannya yang dominan. Seorang guru diharuskan mampu merancang keadaan belajar yang efektif dan efesien.

Beberapa metode belajar dalam strategi pembelajaran tidak langsung, sebagai berikut:

${ }^{18}$ Syaiful Bahri Djamarah dan Aswan Zain, Strategi Belajar Mengajar (Jakarta: Rineka Cipta, 1997), hlm. 109

${ }^{19}$ Ibid

${ }^{20}$ Ibid 
1) Metode Inquiry

Metode Inquiry yaitu proses pembelajaran melalui proses berpikir sistematis dengan penemuan suatu hal. ${ }^{21}$ Peserta didik dilibatkan untuk pengumpulan data dan memperoleh jawaban.. ${ }^{22}$ Peserta didik berperan aktif pada proses pembelajarannya. ${ }^{23}$

Tahapan dalam metode inquiry, yaitu peserta didik memiliki kemampuan menyimpulkan suatu hasil belajar dalam kegiatan penyelidikan sederhana dalam kegiatan belajar dan merumuskan sebuah data. ${ }^{24}$

2) Metode pembelajaran Discovery

Metode Discovery merupakan sebuah strategi yang dalam pelaksanaanya guru memberikan kebebasan kepada peserta didik dalam menemukan sesuatu sendiri. ${ }^{25}$

Pelaksanaan pembelajaran melibatkan peran antara guru dan peserta didik. Guru memberikan arahan, peserta didik juga harus maksimal dalam mengerahkan kemampuan untuk memperoleh sebuah konsep. Sehingga daya ingat mengenai materi pembelajaran bertahan lama. ${ }^{26}$

c. Strategi Pembelajaran Interaktif (Interaktive Instruction)

Startegi berbentuk kelompok diskusi, saling bertukar pengetahuan dan informasi sehingga peserta didik dapat memberikan reaksi terhadap gagasan, pengalaman, dan pandangan kepada guru atau kelompok. Pengembangan dalam metode interaktif, yaitu berupa

${ }^{21}$ Muhamad Afandi, Evi Chamalah, Oktarina Puspita Wardani, Model Dan Metode Pembelajaran Di Sekolah, (Semarang: UNISSULA PRESS, 2013), hlm.44

${ }^{22}$ Paul suparno, Metodologi Pembelajaran Fisika, (Yogyakarta: USD 2013), hlm. 71 Humaniora), hlm. 53

${ }^{23}$ Uus Toharuddin dkk, Membangun Literasi Sains Peserta Didik, (Bandung:

${ }^{24}$ Ahmad susanto Teori Belajar dan Pembelajarandi Sekolah Dasar, (Jakarta: Kencana Media Group, 2013), hlm. 177

25 Paul suparno, Metodologi Pembelajaran Fisika: Konstruktivistik dan Menyenangkan, (Yogyakarta: Universitas Sanata Dharma, 2013), hlm. 79

${ }^{26}$ Nurdin Muhamad, Pengaruh Metode Discovery Learning untuk Meningkatkan Representasi Matematis dan Percaya Diri Siswa, Jurnal Pendidikan Universitas Garut, Vol. 09; No. 01; 2016; 9-22, diunduh pada tanggal 15 Mei 2020 
diskusi kelas, diskusi kelompok kecil, dan kerjasama berpasangan. ${ }^{27}$ Cara ini di susun agar peserta didik aktif dalam bertanya dan mampu menjawab pertanyaannya sendiri dengan melakukan analisis sebelumnya. ${ }^{28}$ Pelaksanaan strategi pembelajaran Interaktif bukan saja melihat hasil akhir namun dilihat dari pemahamanm awal peserta didik. Belajar mewujudkan sebuah "makna" yang dilihat dan didengar kemudian dikembangkan oleh peserta didik. ${ }^{29}$ Strategi ini juga bertujuan mengungkapkan pemikirannya yang akurat dengan melalui bahasa peserta didik sendiri. Peserta didik akan terdorong untuk berfikir kreatif dan imajinatif. Suasana belajar akan kondusif, karena pengungkapan pendapat akan dihargai,dalam hal ini tidak ada hanya ada satu jawaban benar. ${ }^{30}$

Adapun beberapa metode dalam strategi pembelajaran interaktif sebagai berikut: ${ }^{31}$

1) Metode Latihan dengan Teman Sejawat

Pelaksanaan metode ini perlu peran teman yang telah berhasil memahami konsep sebelumnya. Metode ini memberikan kemudahan memahami materi kembali karena diajarkan oleh teman sejawatnya. Yang perlu diperhatikan saat proses metode latihan dengan teman sejawat ini yaitu;

a) Tetap ada pembimbingan dari guru dalam pelaksananya.

b) Setelah menyelesaikan tugasnya, guru akan mengarahkan pada keterampilan peserta didik.

c) Setelah peserta didik berhasil, ia boleh menjadi pelatih temannya yang belum lulus selanjutya

27 Abdul Majid, Strategi Pembelajaran. (Bandung: Remaja Rosdakarya, 2013)

${ }^{28}$ Usman Sumantowa, Pembelajaran IPA di Sekolah Dasar, (Jakarta: Indeks 2011),

hlm. 65

\section{${ }^{29}$ Ibid}

${ }^{30}$ Ibid

${ }^{31}$ Hamdani, Strategi Belajar Mengajar, (Bandung: Pustaka Setia Bndung 2010), hlm. 


\section{2) Metode Diskusi}

Metode yang melibatkan interaksi peserta didik dengan guru dan peserta didik yang lainnya untuk melakukan analisis, menuntaskan persoalan yang ada.

3) Metode belajar kooperatif kelompok

Kooperatif kelompok yaitu metode pembelajaran dalam bentuk kelompok kecil. Pelaksanaan pembelajaran dilakukan dengan kerjasama antar kelompok. Tujuan metode ini untuk melatih peserta didik dalam melakukan kerjasama antar kelompok, jadi bukan hanya sekedar akademik saja. Selain itu mengembangkan keterampilan sosial dengan berinteraksi dengan anggota kelompok. $^{32}$

\section{d. Strategi Belajar Melalui Pengalaman}

Strategi ini lebih didominasi peran peserta didik dan bertujuan pada kegiatan. Strategi ini mementingkan proses belajar ketimbang pada hasilnya. Pelaksanaan strategi ini bissa dilakukan guru baik di dalam atau di luar kelas, contohnya di dalam kelas digunakan metode simulasi, sedangkan diluar kelas dapat dikembangkan metode observasi.

Adapun metode-metode strategi ini sebagai berikut:

1) Metode Eksperimen

Peserta didik dalam melakukan eksperimen melalui langkah mengamati proses percobaan, kemudian menuliskan hasil percobaan yang dilakukan.. ${ }^{33}$ Metode eksperimen terbimbing yaitu metode yang sudah disusun sebelum dilakukan percobaan oleh peserta didik dan Metode ekperimen bebas yaitu metode eksperimen yang pelaksanaannya siswa lebih banyak berfikir

${ }^{32}$ Asmadi Alsa,Pengaruh Metode Belajar Jigsaw Terhadap Keterampilan Hubungan Interpersonal dan Kerjasama Kelompok pada Mahasiswwa Fakultas Psikologi, JURNAL PSIKOLOGI VOLUME 37, NO. 2, Desember 2010: 165 - 175 165, diunduh pada tanggal 20 Mei 2020

${ }^{33} \mathrm{Ai}$ Salsiah, kemampuan menyusun hipotesis dalam pembelajaran ipa Melalui metode eksperimen pada peserta didik Kelas $v$ sekolah dasar, JURNAL PENDIDIKAN DASAR Volume 6 Edisi 2 Desember 2015, diunduh pada tanggal 20 Mei 2020 
sendiri, bagaimana cara siswa dalam melakukan percobaan, dalam hal ini guru tidak memberikan petunjuk pelaksaan secara rinci. ${ }^{34}$

\section{2) Metode Simulasi}

Cara praktek yang digunakan untuk mengembangkan aspek keterampilan peserta didik, baik mental dan fisik. Metode ini menggambarkan situasi yang benar terjadi dan dibawa pada kegiatan belajar dikelas. ${ }^{35}$ Contohnya, pada saat materi gempa bumi, simulasi terjadi gempa bumi, dan harus menyelamatkan diri.

3) Metode Pengamatan Lapangan

Metode pengamatan lapangan yaitu pembelajaran luar kelas atau sekolah, dimana peserta didik akan diajarkan kepedulian terhadap lingkungan. Manfaat metode pembelajaran lapangan ini mampu meningkatkan motivasi belajar peserta didik dikerankan peserta didik mengamati sendiri antara teori yang didapatkan dikelas dan situasi nyata dilapangan. ${ }^{36}$

e. Strategi Pembelajaran Mandiri

Tujuan strategi ini membangun kesadaran dan kemandirian individu peserta didik. Pelaksanaan kegiatan belajar dilakukan dengan batuan guru, teman dalam kelompok kecil. Strategi ini dapat membentuk kemandirian dan tanggungjawab peserta didik. kelemahannya terbilang sulit dalam prosesnya, disebabkan peserta didik belum dewasa.

Adapun metode pembelajaran dalam strategi pembelajaran mandiri yaitu:

1) Proyek Individu

Penugasan dikerjakan mandiri, bentuk tugasnya yaitu mengamati, membaca, dan meneliti.Metode proyek Individu bertujuan

34 Paul suparno, Metodologi Pembelajaran Fisika: Konstruktivistik dan Menyenangkan, (Yogyakarta: Sanata Dharma, 2013), hlm. 87

${ }^{35}$ Poppy K.Devi, Metode-metode dalam Pembelajaran IPA,(Pusat Pengembangan dan Pemberdayaan Pendidik dan Tenaga Kependidikan Ilmu Pengetahuan Alam: PPPPTK IPA, 2010), hlm.12, diunduh pada tanggal 15 Mei 2020

${ }^{36}$ Ria Wulandari, Metode Kunjungan Lapangan Untuk Menanamkan Kepedulian Terhadap Lingkungan Hidup, JURNAL PEDAGOGIA Volume. 5, No. 1, Februari 2016 
membentuk aspek keterampilan pada peserta didik. ${ }^{37}$ Guru akan memberikan waktu yang cukup panjang untuk mengumpulkan tugas proyek individu, karena pengerjaannya memerlukan proses pengamatan dan analisa..

\section{Karakteristik Materi Pokok Ilmu Pengetahuan Alam (IPA) di MI/SD}

Materi pokok yaitu bahan materi belajar yang diajarkan guru. Materi pokok untuk MI/SD meliputi,Bahasa Indonesia, Ilmu Pengetahuan Alam, Matematika, Ilmu Pengetahuan Sosial, Pendidikan Pancasila dan Kewarganegaraan, Pendidikan Jasmani dan Olahraga, serta Seni Budaya dan Prakarya.. ${ }^{38}$ Dalam menyajikan materi ajar guru memiliki perencanaan sebagai acuan dalam proses pembelajaran. ${ }^{39}$ Definisi materi pokok bisa dilihat dari dua sisi. Materi pokok diartikan sebagai segala sesuatu yang harus dipelajari oleh peserta didik, dan dari sisi pendidik maka materi pokok merupakan segala sesuatu yang harus diajarkan atau disampaikan kepada peserta didik. ${ }^{40}$

Salah satu materi pokok di MI/SD adalah Ilmu Pengetahuan Alam (IPA). Ilmu Pengetahuan Alam termasuk pengetahuan dasar mengenai kejadian dialam yang bermanfaat dalam kehidupan manusia. Materi Ilmu pengetahuan Alam dalam isinya meliputi kemampuan memahami, sikap ilmiah dan keterampilan untuk memecahkan permasalahan yang dihadapi. ${ }^{41}$ Tujuan pelajaran IPA digunakan sebagai sarana mempelajari diri sendiri dan alam sekitar. Proses belajarnya peserta didik mengembangkan kemampuannya untuk memahami alam sekitar secara ilmiah. $^{42}$

\footnotetext{
${ }^{37}$ Hamdani,Strategi Belajar Mengajar, (Bandung: Pustakan Setia, 2011), hlm. 163

${ }^{38}$ Tim Magister PGMI FITK UIN Sunan Kalijaga , Pembelajaran Tematk dari Teoritik dan Praktik,( Yogyakarta: Wijan Mahadi karya) hlm, 61

${ }^{39}$ Omar Hamalik, Perencanaan Pengajaran Berdasarkan Pendekatan System, (Jakarta: PT Bumi Aksara, 2011), hlm. 139

${ }^{40}$ Ibid

${ }^{41}$ Trianto, Mendesain Pembelajaran Kontekstual, (Contekstual Teaching Learning) di kelas, (Jakarta: Cerdas Pustaka Publisher, 2008), hlm.70

${ }^{42}$ Ahmad Santoso, Teori Belajar dan Pembelajaran di Sekolah Dasar, Jakarta:
} 
Pada jenjang Madrasah Ibtida'iyah atau Sekolah Dasar, pembelajaran Ilmu Pengetahuan Alam (IPA) berfokus pada sains, Lingkungan, teknologi dan masyarakat. Pelajaran Ilmu Pengetahuan Alam (IPA) berfokus pada pengalaman belajar secara langsung melalui keterampilan proses dan sikap ilmiah yang dilakukan peserta didik dalam sebuah pengamatan untuk mencapai hasil berupa kesimpulan. Ilmu Pengetahuan Alam (IPA) digunakan untuk mengembangkan sifat imajinatif, kemampuan berfikir, peserta didik memerlukan motivasi agar siap menemukan cara baru dalam memecahkan sebuah masalah. ${ }^{43}$

Adapun karakteristik materi pokok Ilmu Pengetahuan Alam (IPA) MI/SD sebagai berikut:

Pembelajaran IPA di MI/SD dapat mengembangkan daya berpikir peserta didik, nantinya bisa diterapkan dalam lingkungan sekitarnyai. Menurut Jacobson dan Bregman, karakteristik materi pokok IPA di MI/SD, sebagai berikut: ${ }^{44}$

a) Ilmu Pengetahuan Alam (IPA)yaitu rangakaian dari konsep, teori, hukum dan prinsip.

b) Proses kritis dan ilmiah dalam pembelajaran IPA meliputi mental dan fisik, dengan mengamati fenomena lingkungan sekitar, dan juga dalam penggunaanya.

c) Rasa keingintahuan, teguh hati, dan ketelitian dalam proses pengamatan kejadian peristiwa di semesta tempat hidupnya.

d) Kebenaran sains atau IPA bersifat subjektif bukan kebenaran yang bersifat objektif.

Kencana, 2013), hlm. 167

${ }^{43}$ Amalia Supriati, Pembelajaran IPA di SD, (Tanggerang Selatan: Univrsitas Terbuka, 2014), hlm. 211

${ }^{44}$ Ahmad Susanto,Teori Belajar dan Pembelajaran di Sekolah Dasar, (Jakarta: Kencana 
5. Relevansi strategi pembelajaran dengan karakteristik materi pokok IPA dalam buku tematik kurikulum 2013 kelas IV tema 2 di MI/SD

Kelas $\quad:$ IV/ Semester I

Tema : 2 Selalu Berhemat Energi

Pembelajaran : 1

Subtema : 1 Sumber Energi

\begin{tabular}{|c|c|c|c|c|}
\hline $\begin{array}{c}\text { Mata } \\
\text { Pelajaran }\end{array}$ & $\begin{array}{c}\text { Karakteristi } \\
\mathbf{k}\end{array}$ & $\begin{array}{c}\text { Materi } \\
\text { pembahasan }\end{array}$ & Strategi & $\begin{array}{c}\text { Relevansi pemilihan } \\
\text { strategi }\end{array}$ \\
\hline IPA & $\begin{array}{l}\text { 1.Ilmu } \\
\text { Pengetahuan } \\
\text { Alam (IPA) } \\
\text { merupakan } \\
\text { kumpulan } \\
\text { dari konsep, } \\
\text { teori, hokum } \\
\text { dan prinsip }\end{array}$ & $\begin{array}{l}\text { Manfaat } \\
\text { energi } \\
\text { matahari } \\
\text { dalam } \\
\text { kehidupan } \\
\text { sehari-hari. } \\
\text { Mengidentifik } \\
\text { asi sumber } \\
\text { daya alam dan } \\
\text { pemanfaatann } \\
\text { ya. }\end{array}$ & $\begin{array}{l}\text { Strategi } \\
\text { pembelajara } \\
\text { n langsung, } \\
\text { Strategi } \\
\text { interaktif } \\
\text { dengan } \\
\text { metode } \\
\text { diskusi } \\
\text { kelompok }\end{array}$ & $\begin{array}{l}\text { strategi ini menumbuhkan } \\
\text { minat peserta didik dalam } \\
\text { belajar, peserta didik diberikan } \\
\text { informasi terlebih dahulu } \\
\text { terkait manfaat energi } \\
\text { matahari, dan strategi yang } \\
\text { digunakan juga mendorong } \\
\text { siswa untuk berfikir kritis, } \\
\text { melatih komunikasi antara } \\
\text { teman kelompok dalam } \\
\text { mengidentifikasi sumber daya } \\
\text { alam dan pemanfaatannya }\end{array}$ \\
\hline
\end{tabular}

Kelas

: IV/ Semester 1

Tema

: 2 Selalu Berhemat Energi

Pembelajaran

: 3

Subtema

: 1 Sumber Energi

\begin{tabular}{|c|c|c|c|c|}
\hline $\begin{array}{c}\text { Mata } \\
\text { Pelajaran }\end{array}$ & Karakteristik & $\begin{array}{c}\text { Materi } \\
\text { Pembahasan }\end{array}$ & Stra & Relevansi Pemilihar \\
\hline IPA & $\begin{array}{l}\text { 1.Proses ilmiah } \\
\text { dalam } \\
\text { pembelajaran } \\
\text { IPA dapat } \\
\text { berupa mental } \\
\text { dan fisik, serta } \\
\text { dengan } \\
\text { mengamati } \\
\text { fenomena } \\
\text { yang ada di } \\
\text { alam sekitar } \\
\text { termasuk } \\
\text { dalam } \\
\text { penerapannya }\end{array}$ & $\begin{array}{l}\text { Pemanfaatan } \\
\text { angin sebagai } \\
\text { sember } \\
\text { energi. } \\
\text { Membuat dan } \\
\text { mengamati } \\
\text { gerak kincir } \\
\text { angin }\end{array}$ & $\begin{array}{l}\text { Strategi } \\
\text { pembelajar } \\
\text { an langsung } \\
\text { dengan } \\
\text { tanya } \\
\text { jawab,dan } \\
\text { praktek, } \\
\text { Strategi } \\
\text { Eksperiensi } \\
\text { al, metode } \\
\text { pengamatan } \\
\text { lapangan }\end{array}$ & $\begin{array}{l}\text { Strategi ini sesuai dengan materi } \\
\text { pembahasan dan karakteristik } \\
\text { IPA, melalui strategi } \\
\text { pembelajaran langsung dengan } \\
\text { tanya jawab, guru memberikan } \\
\text { beberapa pertanyaan terkait } \\
\text { sumber energi, untuk melatih } \\
\text { keterampilan peserta didik } \\
\text { praktek untuk membuat kincir } \\
\text { angin. Kemudian melakukan } \\
\text { pengamatan lapangan } \\
\text { menentukan arah angin melalui } \\
\text { pergerakkan kincir angin yang } \\
\text { telah dibuat bersama. }\end{array}$ \\
\hline
\end{tabular}

Prenada Media Group, 2013), hlm.170 
Kelas $\quad$ : IV/ semester 1

Tema : 2 Selalu Berhemat Energi

Pembelajaran: 1

Subtema : 2 Manfaat Energi

\begin{tabular}{|c|c|c|c|c|}
\hline $\begin{array}{c}\text { Mata } \\
\text { Pelajaran }\end{array}$ & Karakteristik & $\begin{array}{c}\text { Materi } \\
\text { Pembahasan }\end{array}$ & Strategi & $\begin{array}{c}\text { Relevansi Strategi } \\
\text { Pembelajaran }\end{array}$ \\
\hline IPA & $\begin{array}{l}\text { 1.IPA } \\
\text { merupakan } \\
\text { kumpulan dari } \\
\text { konsep, teori, } \\
\text { hukum dan } \\
\text { prinsip } \\
\text { 2.Proses } \\
\text { ilmiah dalam } \\
\text { pembelajaran } \\
\text { IPA dapat } \\
\text { berupa mental } \\
\text { dan fisik, } \\
\text { sertadengan } \\
\text { mengamati } \\
\text { fenomena } \\
\text { yang ada di } \\
\text { alam sekitar } \\
\text { termasuk } \\
\text { dalam } \\
\text { penerapannya. }\end{array}$ & $\begin{array}{l}\text { Bacaan } \\
\text { tentang } \\
\text { tanaman obat } \\
\text { sebagai } \\
\text { bagian dari } \\
\text { sumber daya } \\
\text { alam } \\
\text { Menemukan } \\
\text { informasi } \\
\text { Sumber } \\
\text { Daya Alam, } \\
\text { manfaat dan } \\
\text { tempat } \\
\text { pemasaranny } \\
\text { a. } 45\end{array}$ & $\begin{array}{l}\text { Strategi } \\
\text { Pembelajaran } \\
\text { Langsung, } \\
\text { Strategi } \\
\text { pembelajaran } \\
\text { interaktif } \\
\text { dengan } \\
\text { metode } \\
\text { kooperatif } \\
\text { kelompok, } \\
\text { metode } \\
\text { pengamatan } \\
\text { lapangan }\end{array}$ & $\begin{array}{l}\text { Stratei pembelajaran } \\
\text { langsung relevan } \\
\text { digunakan, peserta } \\
\text { didik diberikan } \\
\text { konsep mengenai } \\
\text { tanaman obat dan } \\
\text { sumber daya alam } \\
\text { agar memiliki } \\
\text { pemahaman yang } \\
\text { sama. Strategi } \\
\text { pembelajaran } \\
\text { interaktif, metode } \\
\text { kooperatif kelompok } \\
\text { juga relevan untuk } \\
\text { mendiskusikan } \\
\text { bersama pemanfaatan } \\
\text { sumber daya alam dan } \\
\text { pengelolaannya untuk } \\
\text { kehidupan. }\end{array}$ \\
\hline
\end{tabular}

Kelas $\quad:$ IV/ Semester 1

Tema : 2 Selalu Berhemat Energi

Pembelajaran: 3

Subtema : 2 Manfaat Energi

\begin{tabular}{|c|c|c|c|c|}
\hline $\begin{array}{c}\text { Mata } \\
\text { Pelajaran }\end{array}$ & Karakteristik & $\begin{array}{c}\text { Materi } \\
\text { Pembahasan }\end{array}$ & Strategi & $\begin{array}{c}\text { Relevansi Strategi } \\
\text { Pembelajaran }\end{array}$ \\
\hline IPA & $\begin{array}{l}\text { 1.Proses } \\
\text { ilmiah dalam } \\
\text { pembelajaran } \\
\text { IPA dapat } \\
\text { berupa mental } \\
\text { dan fisik, serta } \\
\text { dengan }\end{array}$ & $\begin{array}{l}\text { Benda-bend } \\
\text { a elektronik } \\
\text { dan cara } \\
\text { aman } \\
\text { menggunak } \\
\text { an listrik }\end{array}$ & $\begin{array}{l}\text { Strategi } \\
\text { pembelaaran } \\
\text { langsung, } \\
\text { Pembelajaran } \\
\text { melalui } \\
\text { pengalaman } \\
\text { metode }\end{array}$ & $\begin{array}{l}\text { Strategi pembelajaran } \\
\text { langsung relevan } \\
\text { digunakan guru untuk } \\
\text { menjelaskan jenis-jenis } \\
\text { benda elektronik dengan } \\
\text { melihat benda-bends } \\
\text { sekitar baik dirumah/ }\end{array}$ \\
\hline
\end{tabular}

${ }^{45}$ Anggi St. Anggari, Afriki, Dkk, Buku Siswa Tematik Kurikulum 2013 kelas IV Tema 2, (Jakarta: Kementerian Pendidikan dan Kebudayaan, 2016), hlm. 4-117 


\begin{tabular}{lll}
\hline mengamati & simulasi & sekolah. Tanya jawab \\
fenomena yang & Strategi & diberikan kepada peserta \\
ada di alam & pembelajaran & didik agar suasana belajar \\
sekitar & mandiri & menjadi aktif. Setelah \\
2.Rasa & metode & itu guru memberikan \\
keingintahuan, & proyek & simulasi cara \\
sikap teguh & penelitian & menggunakan listrik \\
ketekunan & & dengan aman. Untuk \\
dalam & & memberikan pelajaran \\
mengamati & & yang mendalam, peserta \\
rahasia alam & & didik diberikan tugas \\
& & rumah melakukan proyek \\
& & tata cara menggunakan \\
\hline
\end{tabular}

Kelas

: IV/ Semester 1

Tema

\section{: 2 Selalu Berhemat Energi}

Pembelajaran: 1

Subtema : 3 Energi Alternatif

\begin{tabular}{|c|c|c|c|c|}
\hline $\begin{array}{c}\text { Mata } \\
\text { Pelajaran }\end{array}$ & Karakteristik & $\begin{array}{c}\text { Materi } \\
\text { Pembahasan }\end{array}$ & Strategi & $\begin{array}{c}\text { Relevansi Strategi } \\
\text { Pembelajaran }\end{array}$ \\
\hline IPA & $\begin{array}{l}\text { 1.IPA merupakan } \\
\text { kumpulan dari } \\
\text { konsep, teori, } \\
\text { hukum dan } \\
\text { prinsip } \\
\text { 2.Proses ilmiah } \\
\text { dalam } \\
\text { pembelajaran } \\
\text { IPA dapat berupa } \\
\text { mental dan fisik, } \\
\text { serta dengan } \\
\text { mengamati } \\
\text { fenomena yang } \\
\text { ada di alam } \\
\text { sekitar termasuk } \\
\text { dalam } \\
\text { penerapannya }\end{array}$ & $\begin{array}{l}\text { Pemanfaat } \\
\text { an sumber } \\
\text { energi } \\
\text { alternatif }\end{array}$ & $\begin{array}{l}\text { Strategi } \\
\text { pembelajara } \\
\text { n tidak } \\
\text { langsung } \\
\text { metode } \\
\text { inkuiri } \\
\text { terbimbing, }\end{array}$ & $\begin{array}{l}\text { Strategi inkuiri ini } \\
\text { memberikan } \\
\text { kesempatan kepada } \\
\text { peserta didik untuk } \\
\text { berpikir sistematis } \\
\text { untuk mencari } \\
\text { pemanfaatan sumber } \\
\text { energi alternatif, } \\
\text { mencoba melakukan } \\
\text { percobaan yang } \\
\text { berkaitan dengan } \\
\text { pemanfaatan energi } \\
\text { alternatif. }\end{array}$ \\
\hline
\end{tabular}


Kelas $\quad:$ IV/ Semester 1

Tema : 2 Selalu Berhemat Energi

Pembelajaran: 3

Subtema : 3 Energi Alternatif ${ }^{46}$

\begin{tabular}{|c|c|c|c|c|}
\hline $\begin{array}{c}\text { Mata } \\
\text { Pelajaran }\end{array}$ & Karakteristik & $\begin{array}{c}\text { Materi } \\
\text { Pembahasan }\end{array}$ & Strategi & $\begin{array}{c}\text { Relevansi Strategi } \\
\text { Pembelajaran }\end{array}$ \\
\hline IPA & $\begin{array}{l}\text { 1.IPA } \\
\text { merupakan } \\
\text { kumpulan } \\
\text { dari konsep, } \\
\text { teori, hukum } \\
\text { dan prinsip } \\
\text { 3. Kebenaran } \\
\text { IPA bersifat } \\
\text { subjektif } \\
\text { bukan } \\
\text { kebenaran } \\
\text { yang bersifat } \\
\text { objektif }\end{array}$ & $\begin{array}{l}\text { Mengidentifikasi } \\
\text { manfaat } \\
\text { perubahan } \\
\text { sumber energi. }\end{array}$ & $\begin{array}{l}\text { Strategi } \\
\text { pembelaja } \\
\text { ran tidak } \\
\text { langsung } \\
\text { metode } \\
\text { discovery, } \\
\text { pembelaja } \\
\text { ran } \\
\text { eksperiens } \\
\text { ial metode } \\
\text { eksperime } \\
\mathrm{n}\end{array}$ & $\begin{array}{l}\text { Strategi ini relevan } \\
\text { dengan materi metode } \\
\text { discovery dapat dijadikan } \\
\text { strategi untuk } \\
\text { memberikan kesempatan } \\
\text { kepada peserta didik } \\
\text { mencari perubahan energi } \\
\text { disekitarlingkungan. } \\
\text { misalnya jeruk, kentang, } \\
\text { apel yang bisa berubah } \\
\text { menjadi energi listrik. } \\
\text { Guru juga bisa } \\
\text { menggunakan metode } \\
\text { eksperimen berkelompok } \\
\text { untuk pembuktian. }\end{array}$ \\
\hline
\end{tabular}

\section{Rumusan Strategi Pembelajaran yang Relevan dengan Materi Pokok IPA} dalam Buku Tematik Kurikulum 2013 Kelas IV Tema 2 MI/SD.

Rumusan strategi pembelajaran ini didapatkan dari hasil analisis relevansi strategi pembelajaran dengan karakteristik materi pokok IPA dalam buku tematik kurikulum 2013 kelas IV tema 2 di MI/SD. Analisis dilakukan dengan mengacu pada buku pegangan guru dan buku pegangan siswa. dalam hal ini peneliti mengambil analisis pada buku kelas IV semester 1, Tema 2 dan berfokus pada mata pelajaran Ilmu Pengetahuan Alam (IPA). Dari analisis yang dilakukan kesimpulan rumusan strategi pembelajaran yang relevan dengan materi pokok IPA sebagai berikut;

Strategi pembelajaran langsung dengan metode ceramah, tanya jawab, metode latihan, dan demonstrasi (praktek) dapat dipilih dan digunakan dalam mata pelajaran Ilmu Pengetahuan Alam (IPA). Hal ini karena bisa dikaitkan

${ }^{46}$ Anggi St. Anggari, Afriki, Dkk, Buku Guru Tematik Kurikulum 2013 kelas IV Tema 2, (Jakarta: Kementerian Pendidikan dan Kebudayaan, 2016), hlm. 9-122 
antara materi pembahasan dan karakteristik materi pokok IPA. Selain itu bisa menggunakan metode latihan dan praktek(demonstrasi), karena materinya berhubungan dengan percobaan sederhana yang bisa dicoba di dalam kelas. ${ }^{47}$

Strategi pembelajaran tidak langsung metode inquiri dan metode discovery, juga bisa digunakan sebagai strategi pelajaran IPA, dapat mengasah pemikiran kritis sistematis pada diri peserta didik. Peserta didik lebih aktif, guru siap memfasilitasi dan mengarahkan. Pelaksanaanya bisa dibuat dalam bentuk kelompok sehingga melatih proses komunikasi dan pertukaran ide, sehingga menjadi satu kesimpulan yang utuh. ${ }^{48}$

Strategi melalui pengalaman metode simulasi, eksperimen, pengamatan lapangan secara relevansinya bisa dipilih guru saat proses pembelajaran IPA. Ilmu Pengetahuan Alam erat hubungannya dengan alam sekitar yang ada di kehidupan manusia. Strategi pengamatan lapangan sangat membantu proses belajar menjadi nyata, karena peserta didik mengalami langsung sebagaimana konsep yang telah dipelajari di dalam buku pelajarannya. Strategi simulasi dan eksperimen juga memberikan pembelajaran bukan sekedar teori namun ada karya dan percobaan yang dilakukan. ${ }^{49}$

Strategi pembelajaran mandiri metode proyek penelitian dapat digunakan pada pelajaran IPA, startegi ini dapat dipilih oleh guru untuk menambah proses pemahaman yang mendalam. Strategi ini bukan hanya butuh peran guru, namun peserta didik yang aktif dan kerja sama dengan orang tua, hal ini dikarenakan proyek penelitian ini memerlukan waktu yang panjang dalam penyelesaiannya. Proses saat meneliti inilah yang akan memberikan pengetahuan peserta didik semakin kritis dan mendalam untuk memecahkan suatu permasalahan. ${ }^{50}$

${ }^{47}$ Anggi St. Anggari, Afriki, Dkk, Buku Siswa Tematik Kurikulum 2013 kelas IV Tema 2, (Jakarta: Kementerian Pendidikan dan Kebudayaan, 2016), hlm. 4-117

${ }^{48}$ Nunuk Suryani \& Leo Agung, Strategi Belajar Mengajar, Yogyakarta: Penerbit Ombak, 2012), hlm. 119

${ }^{49}$ Suci Perwita Sari Upaya Meningkatkan Hasil Belajar Siswa Pada Mata Pelajaran IPA Dengan Menggunakan Metode Simulasi, BINA GOGIK, Vol 5 No. 2, September 2018

${ }^{50}$ Iskandar, Psikologi Pendidikan Sebuah Orientasi Baru, (Jambi:Gaung Persada Press), hlm. 90 
Dengan analisis strategi pembelajaran diatas melalui telaah buku tematik kurikulum 2013 kelas IV tema 2 MI/SD, baik buku guru dan buku siswa, didukung dengan jurnal, dokumen, dan buku lainnya, mendapatkan hasil strategi pembelajaran yang relevan dengan materi pokok IPA kelas IV tema 2 MI/SD, yaitu dengan strategi melalui pengalaman metode eksperimen dan pengamatan lapangan. Kelas empat adalah pondasi awal peserta didik menerima mata pelajaran IPA yang sebelumnya tidak didapatkan dikelas satu sampai tiga. Sehingga dalam proses penyampaian materi pokok IPA guru harus berfokus untuk membentuk kerangka dasar materi pokok IPA yang mudah dipahami dan konseptual, selain itu kondisi perkembangan anak diusia jenjang kelas empat juga belum maksimal jika hanya diberikan konsep tanpa ada bukti benda atau fenomena yang bisa dirasakan Strategi pembelajaran melalui pengalaman metode eksperimen dan pengamatan lapangan cocok digunakan, karena dalam penerapannya peserta didik diajak langsung untuk melakukan percobaan dan melihat keadaan sekitar terkait materi yang sedang dipelajari. Startegi pembelajaran ini diharapkan memberikan dampak pada proses pembelajaran materi pokok IPA yang sistematis, inoatif, menyenangkan, dan bisa terasa nyata.

\section{Kesimpulan}

Berdasarkan analisis strategi pembelajaran IPA dalam Buku Tematik Kurikulum 2013 Kelas IV Tema 2 di MI/SD, ada beberapa simpulan yang dapat dibuat. Pertama, Strategi pembelajaran bagian dari serangkaian tindakan untuk mewujudkan kegiatan belajar yang efektif dan efisien. Kedua, jenis strategi dalam menyampaikan materi pokok/ajar MI/SD di kelas IV bermacam-macam, penelitian ini berfokus pada materi pokok IPA yang memiliki karakteristik meliputi, kumpulan teori bersifat ilmiah, prosesnya bisa dilihat dialam sekitar, kebenarannya subjektif bukan objektif. Ketiga rumusan, relevansi strategi pembelajaran dengan karakteristik materi pokok IPA dalam buku tematik kurikulum 2013 kelas IV tema 2 di MI/SD yaitu ada beberapa strategi yang bisa digunakan untuk membuat poses belajar IPA di 
MI/SD menjadi aktif dan menyenangkan. dalam hal ini analisa penelitian terkait strategi pembelajaran yang relevan dengan materi pokok IPA di kelas IV tema 2 MI/SD yaitu strategi pembelajaran melalui pengalaman metode eksperimen dan pengamatan lapangan.

Selanjutnya beberapa saran sehubungan dengan analisis strategi pembelajaran materi pokok IPA dalam buku tematik kurikulum 2013 kelas IV tema 2 yaitu, bagi guru agar lebih mempersiapkan strategi pembelajaran yang dikondisikan dengan keadaan lingkungan, peserta didik dan karakteristik materi pokok MI/SD. Untuk peneliti selanjutnya, menyiapkan data-data berkaitan dengan pembahasan yang akan diangkat menjadi penelitian, agar mempermudah penulisan, lebih semangat lagi untuk menuangkan permasalahan yang terjadi terutama didunia pendidikan,agar menjadi bahan evaluasi dan perbaikan. 


\section{DAFTAR PUSTAKA}

Afandi, Muhamad, Evi Chamalah, Oktarina Puspita Wardani, Model Dan Metode Pembelajaran Di Sekolah, Semarang: UNISSULA PRESS, 2013.

Ai Salsiah, Kemampuan menyusun hipotesis dalam pembelajaran ipa Melalui metode eksperimen pada peserta didik Kelas v sekolah dasar, JURNAL PENDIDIKAN DASAR Volume 6 Edisi 2 Desember2015, diunduh pada tanggal 20 Mei 2020

Alsa,Asmadi, Pengaruh Metode Belajar Jigsaw Terhadap Keterampilan Hubungan Interpersonal dan Kerjasama Kelompok pada Mahasiswa Fakultas Psikologi, JURNAL PSIKOLOGI VOLUME 37, NO. 2, Desember2010: 165 - 175 165, diunduh pada tanggal 20 Mei 2020

Anggi St. Anggari, Afriki, Dkk, Buku Siswa Tematik Kurikulum 2013 kelas IV Tema 2, Jakarta: Kementerian Pendidikan dan Kebudayaan, 2016.

Anggi St. Anggari, Afriki, Dkk, Buku Guru Tematik Kurikulum 2013 kelas IV Tema 2, Jakarta: Kementerian Pendidikan dan Kebudayaan, 2016.

Asrori, Mohammad, Pengertian, Tujuan dan Ruang Lingkup Strategi Pembelajaran, Jurnal Madrasah, Vol.5. No. 2 Januari- Juni 2013, diunduh pada tanggal 16 Mei 2020

Azimi, Ani Rusilowati, Sulhadi, Pengembangan Media Pembelajaran IPA Berbasis Literasi Sains untuk Siswa Sekolah Dasar, Pancasakti Science Education Journal PSEJ Volume 2 Nomor 2, Oktober 2017, Hal. 145- 145

Bahri, Syaiful Djamarah dan Aswan Zain, Strategi Belajar Mengajar (Jakarta: Rineka Cipta, 1997.

Devi, Poppy K., Metode-metode dalam Pembelajaran IPA,(Pusat Pengembangan dan Pemberdayaan Pendidik dan Tenaga Kependidikan Ilmu Pengetahuan Alam: PPPPTK IPA, 2010), hlm.12, diunduh pada tanggal 15 Mei 2020

Dw. Ayu Indri Wijayanti, Kt. Pudjawan, I Gd. Margunayasa, Analisis Kemampuan Berpikir Kritis Siswa Kelas V Dalam Pembelajaran Ipa Di 3 Sd Gugus X Kecamatan Buleleng,e-Journal PGSD Universitas Pendidikan Ganesha Jurusan PGSD Volume: 3 No: 1 Tahun 2015

Djamarah, Syaiful Bahri dan Aswan Zain, Strategi Belajar Mengajar Jakarta:Rineka Cipta,1997.

Eli Fauzi Rahma, Peningkatan Aktivitas Belajar Ipa Melalui Strategi Pembelajaran Inkuiri Terbimbing Pada Kelas Ivb Sdn Panggang, Jurnal 
Pendidikan Guru Sekolah Dasar Edisi 19 Tahun ke-5 2016

Hamalik, Omar, Perencanaan Pengajaran Berdasarkan Pendekatan System, Jakarta: PT Bumi Aksara, 2011.

Hamdani, Strategi Belajar Mengajar, Bandung: Pustakan Setia, 2011.

Harmuni, Strategi Pembelajaran,Yogyakarta: Insan Madani, 2012.

Heruman, Model Pembelajaran Matematika di Sekolah Dasar, Bandung:Remaja Rosdakarya, 2013.

Hidayati, Konsep Pendidikan IPS Dan Karakteristik Pendidikan IPSdi SD,

Irawati,ErniSurya, ImamSuyitno, WidodoHs, Karakteristik Bahasa Indonesia Tuturan Siswa Kelas I Sdn Kesatrian 1 Malang Dalam Interaksi Belajar Mengajar, diunduh di http://jurnal-online.um.ac.id/data/artikel/, pada tanggal 15 Mei 2020.

Majid, Abdul, Pembelajaran Tematik Terpadu, Bandung: Remaja Rosdakarya, 2014.

Malik,Muh Syauqi, Analisis Hots, 4c, Literasi, Dan Pendidikan Karakter Dalam Seni Budaya Dan Prakarya Mi/Sd Kurikulum 2013, Elementary Vol. 8 No.1Januari - Juni 2020, diunduh pada tanggal 17 Mei 2020.

Muhamad, Nurdin, Pengaruh Metode Discovery Learning untuk Meningkatkan Representasi Matematis dan Percaya Diri Siswa, Jurnal Pendidikan Universitas Garut, Vol. 09; No. 01; 2016; 9-22, diunduh pada tanggal 15 Mei 2020

Nasaruddin, Nasaruddin, “Karakterisik Dan Ruang Lingkup Pembelajaran Matematika Di Sekolah,” Al-Khwarizmi: Jurnal Pendidikan Matematika dan Ilmu Pengetahuan Alam Vol 1, no. 2 (2013): 63-76, diunduh dari: https://ejournal.iainpalopo.ac.id/index.php/al-khwarizmi/article/view/93/79, pada tanggal 15 Mei 2020.

Nasution, Wahyudin Nur, strategi Pembelajaran, (Medan, Perdana Publishing, 2017.

Paulsuparno, Metodologi Pembelajaran Fisika: Konstruktivistik dan Menyenangkan, Yogyakarta: Universitas Sanata Dharma, 2013.

Permendikbud No 22 Tahun 2016, Jakarta: Kemendikbud 2016.

Prastowo, Andi, Menyusun Rencana Pelaksanaan Pembelajaran (RPP) TematikTerpadu, Jakarta:Prenada Media, 2015. 
Purwanto, N, Prinsip-prinsip dan teknik Evaluasi Pengajaran, (Bandung: Remaja Rosdakarya, 2004

Samsuri, Paradigma Pendidikan Kewarganegaraan Dalam Kurikulum 2013, Yogyakarta: Fakultas Ilmu Sosial UNY

Sari, Suci Perwita, Upaya Meningkatkan Hasil Belajar Siswa Pada Mata Pelajaran IPA Dengan Menggunakan Metode Simulasi, BINA GOGIK, Vol 5 No. 2, September 2018

Sugiyono, Metode Penelitian Kuantitatif, Kualitatif dan R\&D, Alfabeta, 2012

Suharsimi, Arikunto, , Prosedur Penelitian Suatu Pendekatan Praktik, Rineka Cipta, 2010

Susanto, Ahmad Teori Belajar dan Pembelajarandi Sekolah Dasar, Jakarta: KencanaMedia Group, 2013.

Supriati, Amalia,Pembelajaran IPA di SD, (Tanggerang Selatan: Univrsitas Terbuka, 2014

Suryani, Nunuk \& Leo Agung, Strategi Belajar Mengajar,Yogyakarta: Penerbit Ombak, 2012

Suyono dan Hardianto, Belajar dan pembelajaran: Teori dan konsep Dasar,Bandung: Remaja Rosdakarya, 2011.

Tim Magister PGMI FITK UIN Sunan Kalijaga , Pembelajaran Tematk dari Teoritik dan Praktik, Yogyakarta: Wijan Mahadi karya

Tobing, Rangke L, Setia Adi Hindun, Model-Model Mengajar Metodik Khusus Pendidikan Ilmu Pengetahuan Alam Sekolah Dasar, diunduh pada tanggal 16 Mei 2020

Toharuddin, Uus, Sri Hendrawati, Membangun Literasi Sains Peserta Didik, Bandung: Humaniora, 2011.

Trianto, Mendesain Pembelajaran Kontekstual, (Contekstual Teaching Learning) di kelas, (Jakarta: Cerdas Pustaka Publisher, 2008), hlm.70

Usman Sumantowa, Pembelajaran IPAdi Sekolah Dasar, Jakarta: Indeks 2011.

Wulandari,Ria, Metode Kunjungan Lapangan Untuk Menanamkan Kepedulian Terhadap Lingkungan Hidup, JURNAL PEDAGOGIA Volume. 5, No. 1, Februari 2016 
